\title{
Socio cultural and agricultural local wisdom by cetho indigenous community to preserve the nature
}

\author{
Kadhung Prayoga ${ }^{1)^{*}}$, Adietya Muhammad Riezky ${ }^{1)}$, Aditya Rafi Syuhada ${ }^{1)}$, Dimas Setyo Prayoga ${ }^{2)}$ \\ ${ }^{1}$ Agribusiness, Agriculture Department, Fakulty of Animal and Agricultural Sciences, Diponegoro University, Semarang, Indonesia \\ ${ }^{2}$ Management, Faculty of Economics and Business, UPN Veteran Yogyakarta, Yogyakarta, Indonesia \\ Email: kadhungprayoga@gmail.com
}

Article Information: Received: 06/01/2020 Reviewed: 08/01/2020 Accepted: $15 / 03 / 2020$

\section{(c) (i)}

Copyright (c) 2020 Kadhung Prayoga, Adietya Muhammad Riezky, Aditya Rafi Syuhada, Dimas Setyo Prayoga
ABSTRACT: The development strategy which is the big push is gradually getting eliminates the values of local wisdom in farming activity. Farmers are directed in uniformity, from the use of the seeds, fertilizers, and pesticides. As a result, many local plant seeds began to become extinct and replaced by new varieties that are sometimes incompatible with the environment. For this reason, this paper is present with the aim of seeing how the local wisdom plays a role in agricultural practices in Cetho Hamlet, especially in terms of seedling onion. The approach used is a qualitative approach using a descriptive method. The data used are the primary and secondary data collected through methods of the study of literature, interviews, and observation. From the discussion, it is known that in agricultural practices conducted by the people of Cetho Hamlet is still full of local traditions. Local wisdom that exists not only related to the problem of solidarity among the people but has been rooted in the community activities in farming and its efforts to achieve ecological balance. One of them is in the manufacture and storage of onion seeds. This local wisdom has been obtained from generation to generation and practiced daily. However, it is necessary to study from the government or researchers related to onion seeds produced like this in the framework of the development of nature conservation based on local knowledge of the community.

Keyword: agriculture, indigenous community, local wisdom, onion, seedling

Citation: Prayoga, K., Riezky, A. M., Syuhada, A. R., \& Prayoga, D. S. (2020). Socio cultural and agricultural local wisdom by cetho indigenous community to preserve the nature. AGROMIX, 11(1), 21-31. https://doi.org/10.35891/agx.v11i1.1843

\section{INTRODUCTION}

Globalization which includes the development of genetic manipulation has a negative impact on the existence of the original germplasm of a region. Many plant seeds begin to become extinct and replaced by new varieties that sometimes do not fit with the farmer's environment. As a result farmers are also reluctant to use local varieties and began to occur dependence with varieties of certain manufacturers. Local varieties that have proven their adaptability and productivity are not considered in accordance with the purpose of farmers to obtain maximum profit. Varieties of plants from the company are able to provide greater yields and income, but this has been lulling the farmers.

This phenomenon is common in rural Indonesia. Especially after the green revolution that has had a major effect on the changing way of farming the village community. The green revolution has tried to generalize the way of farming society, ranging from seeds used, sowing fertilizer, to pesticides. No more dynamics because all generalized by the government. The strategy of development that 
is big push is gradually remove the values of local wisdom of farmers in farming activities. The paradigm that says that there should be a balance in the ecosystem began to waver due to the entry of foreign varieties. Economic pressure and the emergence of cutting-edge technology also contributes to eliminating the noble values that exist in the pattern of farming communities.

Some researchers also explains the similarity that the presence of various introductions of technology into agricultural cultivation has long been happening in Indonesia (Las et al., 2006; Putra 2012). As an innovation, the presence of such technology has resulted in very important results for the growth of the agricultural sector in the past and even increased productivity dramatically. Nevertheless, there are a number of weaknesses that occur behind the success story. Massive technological introductions in the past have resulted in the loss of a number of agricultural institutions in rural areas, declining environmental quality, and to some extent changing the values and norms of rural areas. Even the green revolution has caused environmental problems and the disappearance of local varieties from the market.

Even people in developing countries have abandoned their resources, even trying to forget the more independent and environmentally friendly traditional technologies (Adimihardja, 1999; Dwiyanto \& Priyanti, 2009; Santoso, 2005). This happens because of various pressures, mainly economic reason. However, today all that began to be addressed by the start realizing the importance of local varieties and the application of local wisdom in farming. Not all peasants abandoned the old system that their ancestors had descended. One of them is a farmer who is live at the foot of Mount Lawu, Karanganyar Regency, Central Java Province. Residents who sustain their lives from agriculture and tourism and still living in harmony with nature. Their nature is treated according to the advice of their ancestors. Local wisdom is well preserved, even into the values and norms that govern the daily lives of people. Starting from the nursery, land preparation, to harvesting farmers in Cetho Hamlet is really guided by existing local wisdom.

Local wisdom itself as a tool of knowledge and good practices that originate from previous generations as well as from experiences related to the environment and other communities belonging to a community somewhere that is used for resolve and correctly the various problems and / or difficulties encountered (Putra 2007). Thus, the local wisdom of the inhabitants is a system of knowledge of the local population gained as a legacy from generation to generation and is a process of life experience. Knowledge system that operates in 
the individual and collective level are the effort to solve the problem of life.

For this reason, this paper comes with a view to seeing how local wisdom plays a role in agricultural and development practices in Cetho Hamlet, Gumeng Village, Karanganyar Regency. Even local wisdom is able to help farmers to achieve food security at the village level. There is something unique when the people here are able to maintain the existence of local wisdom that existed when many people out there who abandoned their traditions because they are considered irrelevant in modern life like today.

\section{IMPLEMENTATION METHOD}

The approach used in writing this paper is a qualitative approach. Meanwhile, the method used is descriptive method. The writing of this paper aim to explain how local indigenous people's wisdom in Cetho Hamlet in cultivating onions and in farming practices undertaken by the community. Data collection techniques used in-depth interviews, observations, and literature study methods to obtain primary and secondary data. In-depth interviews were conducted with a number of informants selected purposively according to the issues, especially to local and informal formal figures. Interviews are conducted freely and focused to provide convenience in digging data in depth about the local wisdom that society has. While the observation is done to determine the real condition of Cetho Hamlet, such as physical condition, socio-cultural conditions, and daily activities of society. The result is then the primary data. For literature study itself used in collecting secondary data in the form of written materials derived from previous research, journals, books, theses, dissertations, and various digital information available on the internet. The analysis uses the interpretation of the researcher by referring to various literature or references relevant to the object of study in writing this paper. The data analysis process starts from reviewing all available data from various sources ie from documents, interviews, observations written in field notes. The next step is to make data reduction done by making abstraction, arrange it in units, then categorized. The final stage of the analysis is to check the validity of data, checks and records to produce an analytical framework that has a frame of meaning while interpreting the data to obtain conclusions.

\section{RESULT AND DISCUSSION}

In agricultural practices conducted by the people of Cetho Hamlet, Gumeng Village, Karanganyar Regency, Central Java is still full of local traditions. Lots of local wisdom possessed by Cetho community, considering the people here are still classified as indigenous people very close to Hindu culture. Local wisdom are the values of life inherited from one generation to the next in the form of religion, culture or 
custom generally in the form of oral in a form of social system of a society (Juniarta et al., 2013; Sibarani, 2012). It is transformed into the original wisdom and knowledge of a society in regulating its life order. The existence of local wisdom in society is the result of a downward adaptation process over a very long period of time against an environment normally inhabited or an environment where interactions are frequent.

What people have before and it applies to the bad condition today is ecological wisdom. The interaction between humans and nature that has occurred for many years gives birth to the adaptive ability of farmers in dealing with climate change and managing the environment (Asmiwyati et al., 2015). Local knowledge can be a social capital for climate change adaptation and food security of farm families (Martinez-baron et al., 2018; Saptutyningsih et al., 2019). Local wisdom is considered to be able to overcome various global environmental problems because it was born from the community and in it there is integration between economic, environment, and socal (Forester, 2019; Vitasurya, 2016). In Bali, Indonesia even recognizes the concept of tri hita karana, which sees the relationship of God, man, and the environment (Asmiwyati et al., 2015).

Like in the research of Jacob set al. (2019) in India, Indian farmers have a local wisdom to grain storage and it can contribute to socio- economic empowerment because it is cheap and eco-friendly. Another example is the farmers in Pakistan who continue to try to cultivate bees so that the pollination process can go according to the ecosystem chain (Ali et al., 2020). Azibo and Kimengsi (2015) and Elum, Modise, and Marr (2017) studies in Africa also show that farmers there can continue to survive drastic climate change due to indigenous adaptation strategies. In Java, Indonesia, farmers also know pranoto mongso as a planting calendar (Retnowati et al., 2014). Such practices have been qualified as knowledge-intensive, as they involve the renewal of agronomic principles (Toffolini et al., 2017).

Local wisdom that exists not only related to the problem of solidarity among the people but has been rooted to regulate how the community cooperates with nature in order to achieve environmental balance. Starting from the nursery, preparing the land, managing the land, planting, to harvest the community already has guidelines from his ancestors that tangible local wisdom. Here, not only gotong royong, traditional ceremony in planting rice, but interesting is how people in Cetho Hamlet can save the traditional onion seeds. And it proved to be able to help farmers from generation to generation.

The local knowledge of Cetho community that has been accepted for generations can be transformed into local wisdom because 
according to (Lubis, 2003), local wisdom is cumulative with hereditary beliefs related to community relations with the environment. Local wisdom has a direct effect on the preservation of the environment inhabited by people who have such wisdom. Traditionally local wisdom is already there to prevent overt access which of course with the consequences of damaging the environment. Thus, local wisdom is not always related to culture, but also about how society can relate to nature. Including here it turns out that farmers in Cetho Hamlet have the experience and knowledge to make superior seeds traditionally. Even this way of farming has become part of the life of farmers in Cetho Hamlet.

This practice basically is a traditional conservation practice based on indigenous knowledge about conservation rules (Abdullah et al., 2014; Dove, 1985; Martiningsih, 2012; Pattinama, 2009; Santoso, 2005; Suhartini, 2009; Wijana, 2013).

They also considers the conservation done by the communities in which they reside are generally carried out through a set of cultural values, knowledge, rules, beliefs, taboo, sanctions, and a number of cultural behaviors that existed from generation to generation and become an abstraction of experience adapting to the environment. And this regulates how should build a balance between the carrying capacity of the natural environment with lifestyle and human needs even become a reference for local communities in managing nature.

Even according to Susilo (2014) this has a positive function for the community because it is more ecologically oriented than market interests. In addition to the reasons of local wisdom, the preservation of seeds of onion is also in response to the effects of the green revolution. In many cases agriculture in Indonesia because of the green revolution appears a tendency to cultivate a crop with certain varieties that tend to be generalized, which subordinates the existence of local varieties previously cultivated regularly in rural areas. Until the result disappeared the local varieties.

In line with this, Kuntariningsih and Mariyono (2014) also argue that the use of technology at that time still leaves the sadness to social, economic and ecological changes. The application of conventional agricultural technology causes the dependence of farmers using chemical fertilizers, seeds, and chemical pesticides. Implementation of cultivation that is less concerned with the survival of ecosystems, making the reduced income of better farmers. Even rational calculations of the spending of agricultural inputs are not counted as profit or loss.

So, Kuntariningsih and Mariyono (2014) put forward the idea of the importance of sustainable agriculture as the management and conservation of the natural resource base, and 
the orientation of technological and institutional change to ensure the achievement and fulfillment of current and future human needs. Sustainable agriculture development conserves land, water, plant and animal genetic resources, does not damage the environment, is technically appropriate, economically feasible and socially acceptable. And one of them is by way of producing its own seeds and developing local varieties that already exist in the community. One of them is by making onion seeds through fogging and drying by farmer community in Cetho Hamlet.

Selection of local onion seeds and varieties becomes central, as this will affect the yields and income of farmers at the ends. In line with this, according to Mariska and Rahayu (2011) in Ismail, Rachmadi, and Bana (2014), superior seed is the determining factor of success in the field that have small, medium, and large farming business. Based on this, it can be assumed that the use of superior local seeds will determine the success of the production. Thus, breeding of superior local varieties is necessary because it can guarantee maximum yields and support the farmers in increasing their income, so that the welfare of farmers can be better.

The processing and storage of seeds, as well as the selection of varieties from a plant have become one of local wisdom in the life of farmers in Indonesia (Sunaryo \& Joshi, 2003; Susilawati et al., 2005).
Farmers in Cetho themselves will choose the seeds from the rest of the harvest crop that is perceived quality. After that the onion seeds will be tied and placed in a place in the kitchen. This place is named anjang-anjang in the local language. Made used wood or bamboo and located in the kitchen ceiling. It is right above the fireplace or cooking stove. The goal is to smoke the fire from the fireplace to onion seeds. According to local farmers, this serves to strengthen the seeds of onion from pests of disease. Seeds shall be stored until the next planting season. This local wisdom has been obtained for generations and they do not buy seeds from outside the village.

Making onion seeds independently is also related to Cetho Hamlet that far away from the farm shop. So, they choose to make their own. In addition to the local wisdom they have but also because there are economic reasons behind it. Access limitations require farmers to spend more money if they want to buy seeds from outside the village. There will be additional costs that have to come out, so farmers prefer to do it on their own. This is as in Gunawan, Hidayat, and Purnomo (2013), which states that there are farmers who make their own seeds to be planted on the grounds of making easy and cost-effective. Thus, money for seeds can be allocated to other matters. The people here are able to think logically and economically and based on local derived wisdom. Thus, in addition to preserving the 
culture, the practice they do also benefits economically.

Some knowledge and local technology of farmers such as the production of traditional onion seeds can be firmly rooted and maintained because in eco-friendly technological innovations that have become the daily practice of farmers and rural communities are generally very familiar with the environment (Gunawan et al., 2013; Hariyanto et al., 2013). They live in a variety of natural ecosystems, and have long coexisted with nature in harmony, so they are well acquainted with various ways of sustainable use of natural resources including seedling of a plant. Superior seedlings result from this traditional breeding is widely applied by farmers in Cetho Hamlet also because this seed has been used previously and has been practiced by other farmers within the same region.

This onion breeding process has been socialized to farmers since they were young by their parents. Even his parents also did not hesitate to teach his children. Since childhood, farmers have known the nursery process. However, so far no studies from the government or researchers related to onion seeds produced like this. Is it more disease resistant and high production or not. This will be good if any development and research related to this local wisdom. Because it can be a pilot project if it turns out to be profitable. Or even be able to help farmers in Cetho Hamlet to produce it in massive way. Given during this production of onion seeds in Cetho Hamlet still done per household and in small scale in accordance with the area of land owned. Not yet to the realm of great production. Even in my opinion this kind of practice can help the government if one day there are unexpected situations and affect on the procurement of onion seeds.

Switch a little to the planting period, even the people here still maintain the gotong royong activities in the process of planting onions. This concept maintained by the community from planting season to harvest. This tradition has existed long ago and is preserved to this day. Gotong royong itself define as an unpaid human exertion for a project or work that is beneficial to the public or useful for development (Koentjaraningrat, 1974). Uniquely gotong royong here done by a multi-religious and multicultural society. Although the majority of people are Hindus, there are also Muslims and Christians. Here all elements of society are connected with the sense to help others. There were never any clashes due to religious issues. In fact, each individual respects their culture.

The people of Cetho Hamlet cooperate in collective action, such as splice system and donation system. Splice is a help in the form of human mobilization to help the completion of large household work, such as home 
construction, farming, marriage, burial, and kenduri or selamatan. Donations are helpful in the form of giving of goods or money for the cost of completion of large household chores such as marriage ceremonies and death ceremonies. Cooperation of citizens is also maintained through the administration of various religious ceremonies and regular meeting every week.

It is also related to the need for affiliation, because farmers as social beings can not live alone without the help of others. This makes the farmers in the village have to live side by side with each other. In the onion planting tradition in Cetho Hamlet, the need for affiliation is indicated by the encouragement of the surrounding community to preserve the tradition of the ancestors as well as the media to interact and strengthen solidarity among them. The holding of this tradition makes the surrounding community interact with neighbors, relatives, and non formal leaders. Thus, can establish good social relations between local communities.

Not only gotong-royong even people still preserve the traditional ceremony before planting onion. The community will look for a good day and give offerings to the God before cultivate the land. This tradition is a legacy of their ancestors who run from time to time as a companion in planting onions. So, they do so in order to seek permission from their ancestors before the cultivation process takes place. The relationship created between people and the environment is manifested by giving the offerings at every procession of onion planting until harvest time arrives. The community has a belief that with the holding of traditional ceremonies, their crops will be safe until the harvest, avoid the pest, the crop will be good, and get a lot of harvests. As well as a form of preserving the natural environment and respecting its ancestors.

The emergence of traditional ceremonies before farming, gotong royong, and the existence of traditional onion breeding according to Ahmad (2006) in Putra et al. (2012) has become the unwritten rules of procedure that become the reference of society. Where the rules of the rule cover all aspects of life, in the form of: (1) the rules of concerning relationships among human beings, (2) the rules of concerning human relationships with nature, plants that are more aimed at nature conservation efforts, and (3) the rules concerning to human relationships with the unseen, such as God and supernatural spirits.

The holding of traditions and ceremonies is also beneficial because it can as a medium in establishing social relationships between communities in order to create a harmonious life, help each other and give each other to the surrounding community. Even unique is the culture and tradition in Cetho Hamlet has been able to attract the rural youth to remain in the village. The rural youth here prefer to be 
farmers rather than having to get out of their village. Because of the strong relationships in the villages, the fertile agricultural land, close to the families, and feeling the income of the agricultural sector is higher, the youths here prefer to become farmers rather than have to become laborers in the city. Life in the city with all its sparkling was not able to attract youth in Cetho Hamlet to urbanize.

If looking at how the onion breeding and local wisdom of farmer version in Cetho Hamlet is basically a positive thing because trying to harmonize with nature. Farmers do not try to depend on seeds from a particular company. The local seedlings that they try are also in accordance with the natural conditions in Cetho Hamlet and more resistant to the disease due to entry into the local native varieties. Even in the frugality of Juniarta et al. (2013) conditions that arise because the community practice of Cetho Hamlet is positive in making model of community based natural resource management. The existence of a system that has strong formed and entrenched in the pores of community life will help enter the mindset how best to utilize the natural environment around. Traditional beliefs here contain a large amount of empirical data related to the phenomena, processes and history of environmental change, thus bringing the implication that traditional knowledge systems can provide useful information for planning and development processes.
The local wisdom, traditions and cultures that exist in the community of Cetho Hamlet have great opportunities to be managed and re-empowered so as to regulate the daily life of the community and the norms and rules that favor the least with the environment. It can even be a reflection for other regions so that the community can be independent in supporting food security at the village level. Even addressing the phenomenon today where many rural youth who do not want to stay in the village. Youth in Cetho Hamlet can be a reflection and an example of why it would prefer to be a farmer. Local wisdom should be a factor when the government makes agricultural programs. Local wisdom like this should take precedence because the local community is a community in direct contact with the environment of the object of development. It is also grounded on the grounds that what will be built must be accepted into the daily part of the local community by not rubbing or even contradicting the sociocultural aspects that lived first and developed long before the program would exist.

As the solution offered by Lubis (2003) that in order to grow and develop a wisdom in natural resource management, it needs at least the following eight steps: (1) establishing concrete resources as the subject of management, accessible to a community, (2) Or ideas for the management of the resource through a participatory process and then 
establish a choice of ways to address the problem, (3) find consensus among stakeholders to gain commitment and support for resource management, (4) formulate management objectives, which are likely to be achieved (5) establishing social networks or social units that become constituents of management, ie those who will become active participants in the process of management and utilization of the results, (6) knit institutions, whether in the form of shared value system, Norms and sanctions and rules (7) establishing trust relationships, based on the guarantee of justice for all parties, and (8) conducting the cycle of social capital utilization by building cohesiveness or integrity among the constituent social networks, affirming institutional implementation, increase trust, and so on repeatedly/cyclically.

In the future there needs to be an assessment from the expert in relation to local knowledge of farmers with scientific results, so that their use can be more convincing for the wider community. In addition, a suggestion from a Sereenonchai and Arunrat (2018) requires the need for participatory communication both at the local and regional levels so that indigenous knowledge can survive. The method must be simple and easy to understand by the public, promotion needs to be done massively.

\section{CONCLUSION}

Local wisdom that exists not only related to the problem of solidarity among the people but has been rooted to regulate how the community cooperates with nature in order to achieve environmental balance. One of them is in the manufacture and storage of onion seeds. This local wisdom they have got for generations and practiced everyday even they do not buy seeds from outside the village. This onion breeding process has been socialized to farmers since they were youth by their parents.

For the next, this will be good if any development and research related to this local wisdom. Because it can be a pilot project for other areas if it turns out to be profitable. Or even be able to help farmers in Cetho Hamlet to produce it in a big scale.

\section{REFERENCES}

Abdullah, M. A., Kamaruzzaman, B. A., Muttaqin, T. M., Imran, Z., As, N. B., \& bin Hasaruddin, H. (2014). Aceh: kebudayaan tepi laut, dan pembangunan. Bandar Publishing.

Adimihardja, K. (1999). Mendayagunakan kearifan tradisi dalam pertanian yang berwawasan lingkungan dan berkelanjutan. Humaniora Utama Press.

Ali, M., Sajjad, A., Farooqi Aslam, M., Bashir Amjad, M., Aslam Naveed, M., Nafees, M., Aslam Naeem, M., Adnan, M., \& Khan Ali, K. (2020). Assessing indigenous and local knowledge of farmers about pollination services in cucurbit agroecosystem of Punjab, Pakistan. Saudi Journal of Biological Sciences, 27(1), 189194.

https://doi.org/10.1016/j.sjbs.2019.07.00 1 
Asmiwyati, I. G. A. A. R., Mahendra, M. S., Arifin, N. H. S., \& Ichinose, T. (2015). Recognizing indigenous knowledge on agricultural landscape in Bali for micro climate and environment control. Procedia Environmental Sciences, 28, 623-629.

https://doi.org/10.1016/j.proenv.2015.07 .073

Azibo, B. R., \& Kimengsi, J. N. (2015). Building an indigenous agro-pastoral adaptation framework to climate change in SubSaharan Africa: Experiences from the North West Region of Cameroon. Procedia Environmental Sciences, 29, 126-127.

https://doi.org/10.1016/j.proenv.2015.07 .214

Dove, M. R. (1985). Peranan kebudayaan tradisional Indonesia dalam modernisasi. Yayasan Obor Indonesia.

Dwiyanto, K., \& Priyanti, A. (2009). Pengembangan industri peternakan berbasis sumber daya lokal . Jurnal Pengembangan Inovasi Pertanian, 2(3), 208-228.

Elum, Z. A., Modise, D. M., \& Marr, A. (2017). Farmer's perception of climate change and responsive strategies in three selected provinces of South Africa. Climate Risk Management, 16, 246-257. https://doi.org/10.1016/j.crm.2016.11.00 1

Forester, J. (2019). Ecological wisdom through deliberative improvisation: Theory and practice in challenging cases. Journal of Urban Management, 8(1), 12-19. https://doi.org/10.1016/j.jum.2018.04.00 3

Gunawan, Hidayat, K., \& Purnomo, M. (2013). Penerapan liovasi teknologi ramah lingkungan pada komunitas petani sayuran (studi di desa Tawangargo, kecamatan Karangploso, kabupaten Malang). HABITAT, 24(1), 20-32.

Hariyanto, Wahyudi, \& Basuki, S. (2013). Identifikasi beberapa kearifan lokal dalam menunjang keberhasilan usahatani padi di Jawa Tengah. Prosiding Seminar
Nasional Fakultas Pertanian Universitas Trunojoyo: Menggagas Kebangkitan Komoditas Unggulan Lokal Pertanian Dan Kelautan, 153-159.

Ismail, A., Rachmadi, M., \& Bana, N. (2014). Eksplorasi jenis-jenis pisang plantain lokal asal desa Sukaharja dan desa Sukamulih Tasikmalaya Jawa Barat sebagai sumber bibit unggul. Dharmakarya: Jurnal Aplikasi Ipteks Untuk Masyarakat, 3(2), 92-97.

Juniarta, H. P., Susilo, E., \& Primyastanto, M. (2013). Kajian profil kearifan lokal masyarakat pesisir pulau gili kecamatan Sumberasih kabupaten Probolinggo Jawa Timur. ECSOFim, 1(1), 11-25.

Koentjaraningrat. (1974). Kebudayaan mental dan pembangunan. Gramedia.

Kuntariningsih, A., \& Mariyono, J. (2014). Adopsi teknologi pertanian untuk pembangunan pedesaan: sebuah kajian sosiologis. Agriekonomika, 3(2), 180-191.

Las, I., Subagyono, K., \& Setiyanto, A. P. (2006). Isu dan pengelolaan lingkungan dalam revitalisasi pertanian. Jurnal Penelitian dan Pengembangan Pertanian, 25(3), 173-193.

Lubis, Z. B. (2003). Menumbuhkan (kembali) kearifan lokal dalam pengelolaan sumberdaya alam di Tapanuli Selatan. Antropologi Indonesia, 29(3), 239-254.

Martinez-baron, D., Orjuela, G., Rodrı, L., Renzoni, G., Marı, A., \& Prager, S. D. (2018). Small-scale farmers in a $1.5^{\circ} \mathrm{C}$ future: The importance of local social dynamics as an enabling factor for implementation and scaling of climatesmart agriculture. Current Opinion in Environmental Sustainability, 31, 112119. https://doi.org/10.1016/j.cosust.2018.02. 013

Martiningsih, N. Gst. Ag. G. E. (2012). Pelestarian subak dalam upaya pemberdayaan kearifan lokal menuju ketahanan pangan dan hayati. Jurnal Bumi Lestari, 12(2), 303-312.

Mobolade Jacobs, A., Bunindro, N., Sahoo, D., \& Rajashekar, Y. (2019). Traditional 
methods of food grains preservation and storage in Nigeria and. Annals of Agricultural Sciences, 64(2), 196-205. https://doi.org/10.1016/j.aoas.2019.12.0 03

Pattinama, M. J. (2009). Pengetahuan klmiskinan dengan kearifan lokal (studi kasus di pulau Buru Maluku dan Surade Jawa Barat). Makara: Sosial Humaniora, 13(1), 1-12.

Putra, A. W. S., Hariadi, S. S., \& Harsoyo. (2012).Pengaruh peran penyuluh dan kearifan lokal terhadap adopsi inovasi padi sawah di kecamatan Montasik kabupaten Aceh Besar. KANAL, 1(1), 85101.

Putra, H. S. A. (2007). Pemberdayaan masyarakat dan pelestarian kawasan: sebuah sketsa pemikiran. Jurnal Konservasi Benda Cagar Budaya Borobudur, 1(1), 17-23.

Retnowati, A., Anantasari, E., Marfai Aris, M., \& Dittmann, A. (2014). Environmental ethics in local knowledge responding to climate change: An understanding of seasonal traditional calendar pranoto mongso and its phenology in karst area of gunungkidul, Yogyakarta, Indonesia. Procedia Environmental Sciences, 20, 785-794.

https://doi.org/10.1016/j.proenv.2014.03 .095

Santoso, L. (2005). Eksistensi kearifan lokal pada petani tepian hutan dalam memelihara kelestarian ekosistem sumberdaya hutan. Jurnal Wawasan, 11(3), 10-20.

Saptutyningsih, E., Diswandi, D., \& Jaung, W. (2019). Land use policy does social capital matter in climate change adaptation? A lesson from agricultural sector in Yogyakarta, Indonesia. Land Use Policy, September 2018, 1-5. https://doi.org/10.1016/j.landusepol.201 9.104189

Sereenonchai, S., \& Arunrat, N. (2018). Practical agricultural communication: Incorporating scienti fi $\mathrm{c}$ and indigenous knowledge for climate mitigation. Kasetsart Journal of Social Sciences, 30, 1-8.

https://doi.org/10.1016/j.kjss.2018.05.01 4

Sibarani, R. (2012). Kearifan lokal: hakikat, peran dan metode tradisi lisan. Asosiasi Tradisi Lisan.

Suhartini. (2009). Kajian kearifan lokal masyarakat dalam pengelolaan sumber daya alam dan lingkungan. Prosiding Seminar Nasional Penelitian, Pendidikan, Dan Penerapan MIPA, 206-218.

Sunaryo, \& Joshi, L. (2003). Peranan pengetahuan ekologi dalam sistem agroforestri. In Bahan Ajaran Agroforestri 7. World Agroforestry Center (ICRAF).

Susilawati, Sabran, M., Ramli, R., Djauhari, D., Rukayah, \& Koesrini. (2005). Pengkajian sistem usaha tani terpadu padikedelai/sayuran-ternak di lahan pasang surut. Jurnal Pengkajian dan Pengembangan Teknologi Pertanian, 8(2), 176-191.

Susilo, R. K. D. (2014). Sosiologi lingkungan. Rajawali Press.

Toffolini, Q., Jeuffroy, M., Mischler, P., Pernel, J., \& Prost, L. (2017). Farmers' use of fundamental knowledge to re-design their cropping systems: situated contextualisation processes. NJAS Wageningen Journal of Life Sciences, 80, 37-47.

https://doi.org/10.1016/j.njas.2016.11.00 4

Vitasurya, V. R. (2016). Local wisdom for sustainable development of rural tourism, case on Kalibiru and Lopati village, province of Daerah Istimewa Yogyakarta. Procedia - Social and Behavioral Sciences, 216, 97-108. https://doi.org/10.1016/j.sbspro.2015.12. 014

Wijana, N. (2013). Pengelolaan hutan berbasis kearifan lokal di desa Tigawasa, kecamatan Banjar, kabupaten Buleleng. Seminar Nasional FMIPA UNDIKSHA III, 226-232. 